\title{
War Zone Acapulco: Urban Drug Trafficking in the Americas
}

\author{
Thiago Rodrigues* \\ Mariana Kalil ${ }^{\star *}$ \\ Roberto Zepeda *** \\ Jonathan D Rosen ${ }^{* * *}$
}

\begin{abstract}
Acapulco epitomises the (in)security of urban zones in the Americas whose geographical, political and economic divisions are exacerbated by the political economy and geopolitics of drug trafficking, as well as by militarised attempts to fight it. Various geographic, political, and economic factors in the Acapulco Metropolitan Zone (AMZ) have impacted drug trafficking and organised crime and contributed to high levels of violence. As a result, Acapulco now ranks among the 50 most violent cities in the world. This article analyses the trends in drug trafficking and organised crime in the AMZ, and highlights the lessons for scholars and policy-makers.
\end{abstract}

Keywords: Drug Trafficking; Urbanisation; Militarisation; Acapulco; Mexico; Criminology; Otherness.

\section{Introduction}

Mexico's 'war on drugs' began in 2006 when President Felipe Calderón launched a military campaign against drug trafficking and organised crime. The results have been underwhelming; in the subsequent decade, the 'war on drugs'1 has resulted in about 200,000 violent deaths, $60 \%$ of which are linked to narcos (drug dealers) or organised crime (Rosen and Zepeda 2016).

Literature about the Mexican war on drugs usually focuses on drug trafficking organisations (DTOs), corrupt police forces, the militarisation of public safety, the so-called

Fluminense Federal University (UFF), Niteroi-RJ, Brazil; th.rodrigues@gmail.com. ORCID iD 0000-00020962-0391.

** University of Brasilia (UnB), Brasilia-DF; Brazil; marianakalil@gmail.com. ORCID iD 0000-0003-13028339.

*** National Autonomous University of Mexico (UNAM), Mexico City, Mexico; zepeda_roberto@hotmail. com. ORCID iD 0000-0001-5811-8296.

$\star * \star *$ Florida International University, Miami-FL, United States; jonathanrosenrosen@gmail.com. ORCID iD 0000-0002-6642-8814 
drug cartels, and Mexico's role in the political economy of drug trafficking in the Americas (Rosen and Zepeda 2016; Langton 2013; Marcy 2010; Ravelo 2011; Sabet 2012; Esquivel 2013; Benítez Manaut 2010; Freeman and Sierra 2005; Jones 2016; Rodrigues 2017). Literature on non-conventional threats to international security usually deal with issues involving the US-Mexican border (Astorga 2015; Esquivel 2013; Jones 2016; Gutiérrez 2007). However, International Relations scholars have paid little attention to other Mexican regions that are increasingly caught up in the dynamics of drug trafficking. This article aims to fill this gap by examining the dynamics of drug trafficking and its repression in the city of Acapulco in the south-eastern state of Guerrero.

One of the major blind spots in the contemporary literature about international security is its lack of attention to the relationship between cities and warfare. Despite the historical connection between cities and warfare since the beginning of human settlement, the emergence of the modern state in Europe in the late Middle Ages pushed security and defensive limits out to state borders (Giddens 1985; Tilly 1990; Ashworth 1991; Graham 2004). However, the city/warfare connection has regained traction after the massive attacks on cities in the so-called total war era which reached its climax during World War II (Keegan 1993). Since 1945, urban warfare has become increasingly related to insurgency and counter-insurgency that have reclaimed matters of security in the colonial world (including the anti-French insurrection in Algeria in the late 1950s and early 1960s), the post-colonial world (including the urban guerrillas in Latin America during the 1960s and 1970s), and industrialised countries (including the Irish Republican Army bombings in the United Kingdom). In recent years, urban terrorism has been added to this array of challenges (Shaw 2004; Ashworth 1991).

In the post-Cold War era, warfare in urban spaces has included confrontations among armed forces, peacekeepers, and various non-state actors, such as those on the streets of Sarajevo and Mogadishu. In this context, security studies have highlighted the blurring of the boundaries between 'national security' and 'public safety' in the Global South as well as the developed world, especially after the worldwide spread of anti-terrorist security strategies in the wake of 9/11 (Gros 2010; Graham 2010; Kaldor 2012; Bigo 2002; Feldman 2004; Corva 2009). As Graham (2004: 3) has noted:

it is no longer adequate to theorise cities as local, bounded sites that are separated from the rest of the world. Similarly, political violence is now fuelled and sustained by transnational networks that can be global and local at the same time.

In addition to the global US 'war on terror', the war on drugs is one of the main ways in which violence is spreading throughout the world, combining the 'transnational militarisation of the police function' (Corva 2009: 161) and the localisation of targets and security policies in urban spaces, especially in the Americas, which are home to the most violent cities in the world. Against this background, we will seek to identify a pattern that will help to describe and explain the urban violence associated with drug trafficking in urban spaces in the Americas. 
Acapulco epitomises the contemporary (in)security dynamics of urban zones in the Americas in which existing geographic, political, and economic boundaries and cleavages are being reinforced by the political economy and geopolitics of drug trafficking, as well as by militarised attempts to fight it. The comparative advantages that allow a given city to participate in drug trafficking in the Americas are similar, and improving our understanding of Acapulco's participation in the continental drug trafficking scheme would help us to better understand the sources of insecurity in American cities, and develop better public policies for addressing urban security in the $21^{\text {st }}$ century.

The data that spurred this research was the appearance of Acapulco in 2011 on lists of the world's deadliest cities, which receive widespread media and other attention every year. Given this, we decided to examine the data sources and methods of classification underpinning these lists. We analyse data from lists published by a civil society organisation, the Citizen Council for Public Security and Criminal Justice (Consejo Ciudadano para la Seguridad Pública y la Justicia Penal, or CCSPJP) as well as data about homicide rates in Mexico provided by the National Institute for Statistics and Geography (Instituto Nacional de Estadística y Geografía, or INEGI). However, we have also examined data from the Igarapé Institute's Homicide Monitor, a common source of information for media reports - including those in The Economist (2017) - on violent cities around the world.

The Homicide Monitor utilises data from the Executive Secretariat of the National System of Public Security (Secretariado Ejecutivo del Sistema Nacional de Seguridad Públi$c a$, or SESNSP), comprising members of the federal, regional and local executive branches of government, whose policies are embedded in partisan issues, and whose tenures are constitutionally limited. It also includes members of the judiciary, namely prosecutors, representatives of the penal system, and the police. Therefore, this body represents role players whose interests are significantly more contextual than those of civil servants, whose liabilities last for a lifetime and follow them on a daily basis, and who tend to be less prone to manipulate data for short-term political gain than the former.

The Secretariado's website lists local and regional committees as part of its structure, but does not specify whom they represent. Representatives of the judiciary and the police are civil servants who tend to concentrate on control, not only due to their roles in the legitimate use of force, but also their focus on containment rather than mediating or negotiating with 'outlaws', especially in the broader landscape of the government's decision to co-operate fully with the United States on the 'war on drugs' through, for instance, the Mérida Initiative.

Regarding the veracity of Mexican data on homicide rates, CCSPJP states:

Just like in other countries, the data extracted from the main official source of the country [Mexico], the Sistema Nacional de Seguridad Pública (SNSP), cannot be fully accepted for two reasons: firstly, the numbers the Sistema insists on presenting depict the amount of investigations that are opened, and not the number of homicides itself (which is troublesome for many reasons, but, for instance, there can be only one investigation opened in regards to multiple murders); 
secondly, it is still well-known that some regional governments governments of states - (who are the ones who feed the Sistema with data) manipulate their figures to portray an inferior homicide rate than the actual one. Before this situation, the homicide numbers offered by the National Institute for Statistics and Geography (INEGI) are of great help. INEGI accounts for homicides, not for the number of investigations that are opened, basing their data on thorough inspections of the administrative archives of homicide reports. Furthermore, INEGI is not political actor hence having significantly less or even no motive to manipulate the numbers (CCSPJP 2017: 34-35; authors' translation).

Therefore, the decision to limit our analysis to CCSPJP and INEGI data is based on methodological considerations, but also has political implications that will be addressed below. Until 2010, Acapulco was not even among the 50 most violent cities in the world. As Table 1 shows, after entering the ranking in 2011, the homicide rate decreased once again, but not enough to return to pre-2011 levels. The reasons for this trend are addressed in Section II of this article.

Table 1: Acapulco's ranking among the violent cities in the world, 2011-2016

\begin{tabular}{lllll}
\hline Year & Rank & Homicides & Population & Rate per $\mathbf{1 0 0 ~ 0 0 0 ~ i n h a b i t a n t s ~}$ \\
\hline 2011 & 4 & 1029 & 804412 & 127,92 \\
2012 & 2 & 1170 & 818853 & 142,88 \\
2013 & 3 & 940 & 833294 & 112,80 \\
2014 & 3 & 883 & 847735 & 104,16 \\
2015 & 4 & 903 & 862176 & 104,73 \\
2016 & 2 & 918 & 810669 & 113,24 \\
\hline
\end{tabular}

Source: CCSPJP.

This next section provide a brief profile of Acapulco's economy, geography, society, policies and politics in relation to the political economy and geopolitics of drug trafficking in the Americas, in an attempt to verify whether the city actually epitomises the contemporary (in)security dynamics of urban areas in the Americas where the production of 'otherness' is exacerbated by the political economy and geopolitics of drug trafficking, as well as by militarisation. We argue that economic, geographic, and political constructions of 'otherness' represent the dependent variables that explain why and how Acapulco epitomises the contemporary (in)security of urban zones in the Americas, through the intervening variable of the war on drugs. 


\section{Contemporary (in)security dynamics in Acapulco}

The south-western Mexican state of Guerrero used to be known for its natural beauty, including high mountain peaks and a delightful coast. In the 1950s, the city of Acapulco was a top tourist destination, with its white beaches frequented by Hollywood movie stars and US jet-setters. Celebrities bought beachfront mansions and even hotels in the city. The destination of John and Jacqueline Kennedy's 1953 honeymoon, and the location of one of Elvis Presley's movies in the 1960s, Acapulco was a place to see and be seen.

However, this seemingly idyllic status swiftly changed into a considerably less hedonistic one. Natural beauty was not necessarily what brought tourists to this Mexican city. The bucolic atmosphere resulted from a combination of geography and demography in a specific era in the international political economy of drug trafficking. By the late 1970s, other Mexican destinations, such as Cancún and Cabo San Lucas, had become more appealing. Acapulco's appeal as a tourist destination declined in the 1980s and 1990s and coincided with the increasing importance of Mexican DTOs in drug trafficking in the Americas. Acapulco became one of the 50 most violent cities in the world during the Mexican government's drug war, which will be explained in more detail below.

\section{Geographic features}

Population geography, as a subfield of human geography, places demographics in a geographic context. The impact of demographic cycles on territory has been studied from several perspectives (Plane 2004). The focus on who occupies what spaces in urban territories also involves scholarly literature from criminology as 'the identification of crime hot spots was perhaps a watershed in refocusing attention on the spatial/location features of crime' (Anselin et al 2000: 215).

According to INEGI, Acapulco had a population of about 110000 in the 1960s. In the 1970s, in a demographic transition similar to those in many Latin American cities, its population grew by $144.51 \%$, a rate that declined to $64.64 \%$ in the 1980 s and to $43.15 \%$ in the 1990 s. In the $21^{\text {st }}$ century, the rates have tended to stabilise. Demographic transitions involve increasing birth rates and slowing death rates, overlapping in developing countries with processes of urbanisation.

The rapid increase in Acapulco's population in the 1970s can be seen as part 'of the complex causal forces behind violent conflicts' (Anselin et al 2000: 12). Goldstone (2012: 12) lists economic development, regime type, and leadership as contextual elements that help to explain the impact of demographic transitions on urban violence. While not explicitly cited, the geopolitical and political-economic dynamics of drug trafficking are among those elements. In fact, we argue that Acapulco's entry into the list of the 50 most violent cities in the world represents an archetype of contemporary (in)security dynamics in urban zones in the Americas affected by drug trafficking, as well as militarised strategies designed to combat such problems.

Since 'population factors may interact and overlap with other such causal forces in varying degrees' (Goldstone 2002:12), the period of the demographic transition in Aca- 
pulco from the 1970s until the 1990s represents a challenge for a state, and especially a city, with limited resources. Acapulco's local administration has not had the institutional capacity to address the increasing population. Guerrero, which is one of the poorest states in Mexico, is defined by high levels of poverty, corruption, and impunity, which have created the conditions for drug trafficking organisations to operate. In recent years, these scenarios have also fostered processes of radicalisation that have significantly contributed, for example, to the current face of urban violence in Latin America, as well as terrorism activities in the Western world (Mathieu and Tolosa 2014; Lyon 2004).

In the course of critical geography, Milton Santos discusses the marginalisation of urban spaces by examining Armstrong's and McGee's concept of metropolitan involution (1968, cited in Santos 1988: 120). In the 1960s, these authors focused attention on the transfer of rural practices to urban spaces during high levels of rural-urban migration. Santos (1988: 126) argued that from then on the situation overtook the mere recreation of rural life in urban spaces: 'the high concentration of the urban poor population creates a cultural background entailing ways of life that are less than modern, not at all dynamic, and make little or no difference to the statistics on economic growth' (Santos 1998: 126).

Santos's understanding of the social relevance of being part of official economic figures, such as GDP rates, entails a rationale that intertwines population geography with human geography: since the informal economy does not provide revenue to the state, or to the most politically influential, official economic role players, it sparks a process of 'otherness' that forges visible and invisible - yet deadly - boundaries in urban settings. The reification of neighbourhoods and people who do not matter to the statistics of economic growth' happens through the identification of these spaces and individuals with urban spaces characterised by a 'new metropolitan involution,' as pointed out by Santos.

Figures 1 and 2 record the incidence of violent crime in the AMZ in 2011 and 2012. The concentration of crime in the metropolitan zones of Colonias Zapata, Renacimiento, Jardines, and Coloso clearly illustrate this process of involution, and its results in terms of violent crime. When analysing these maps, it is important to bear in mind the displacement of violent crime throughout the city following the deployment of federal repressive forces. This displacement will be analysed in the second section of this article, which addresses the recent militarisation of the war on drugs in Acapulco.

\section{Economic and other geographic features}

Criminology also helps us to understand why Acapulco epitomises the contemporary (in) security dynamics of urban zones in the Americas. Considering the economic features of the new metropolitan involution and its visible and intangible boundaries are also helpful in this analysis. For Bursik and Grasmick:

The presumed relationship between economic deprivation and the number of crimes committed by residents of a particular neighborhood is one of the lasting legacies of the research [...] As noted by the theoretical explications [...], their social disorganisation framework 
assumed that this relationship was an indirect one, mediated in turn by the residential instability and heterogeneity of the neighborhood and by the regulatory capacity of the area. Nevertheless, despite the indirect nature of its effect on crime rates, the economic composition of local urban communities was the key ecological factor that set in operation the dynamics associated with social disorganisation (Bursik and Grasmick 1993: 263-264).

In the case of Acapulco, it is precisely the 'Acapulco boomers', effectively trapped in areas of involution, who are caught up in drug trafficking and whose lives are being wasted. Not surprisingly, statistics show that men in their twenties are the main sources of violent labour for DTOs, with 'homicides [...] committed primarily by men and against men' (Heinle et al 2015: 21). These 'worthless boomers', disconnected youths, are more vulnerable to being recruited for the most violent tasks, and more likely to be killed due to disputes among DTOs as well as state repression: 'When separated by age, however, the leading cause of death for young men in Mexico hinges on economic status, since wealthy young men are more likely to die of car accidents, and those of modest means more likely to be murdered' (Heinle et al 2015: 15).

During Acapulco's demographic transition (1970s-1990s), 'US narcotics policy towards Mexico was [considered] ultimately a success, but only because the Mexican government chose to crack down on marijuana and poppy producers and traffickers' (Lupsha 1981: 97). In the mid-1970s, Mexico supplied $90 \%$ of the heroin and $70 \%$ of the marijuana consumed in the United States. In the 1980s, however, only $30 \%$ of those drugs came from Mexico itself, and the country began to serve as a transit zone for cocaine and marijuana destined for the United States from other South American countries (Lupsha 1981).

The diminished role of Mexican DTOs did not mean that the US war on drugs or the repressive policies of the Mexican state had succeeded, but that the drug economy had been reshaped, notably by the rise of Andean cocaine interests in the United States and Western Europe, which displaced the core of this illegal activity to South America (Marcy 2010; Santana 2004). In the process, Mexico lost US funding and other forms of support for combatting drug trafficking, and, despite the US State Department's recognition that crop substitution played a key role in avoiding a relapse, no such policy was implemented (Lupsha 1981: 97). Moreover, politicians and police officials in Acapulco had grown accustomed to the lure of narco-dollars (Lupsha 1981: 100).

The demographic transition and the advent of drug trafficking in Acapulco added to the herd behaviour that drew tourists away from the city. This reduced the revenues of the Guerrero and Acapulco authorities, and therefore their ability to combat drug trafficking, during the very period of the city's demographic transition.

At that time, whether in the form of narco-dollars or anti-narco-dollars, drug trafficking could be associated with progress and even glamour. On the other hand, it has led to strategies of militarisation aimed precisely at neighbourhoods of the new metropolitan involution, transporting borders traditionally associated with international security to the friend-enemy scheme within the city. 
Guerrero's suitability for producing marijuana and poppy, the raw material for heroin, and the AMZ's comparative advantages in relation to the political economy of drug trafficking also need to be factored into the analysis of Acapulco as an archetype of the dynamics of (in)security in the urban spaces of the Americas. This includes the fact that Acapulco's proximity to Puerto Vallarta as well as Baja California and the US Pacific Coast makes it 'a perfect setting for marijuana and poppy production as well as heroin manufacturing' (Kyle 2015: 11).

By 2010, Guerrero was already on the verge of surpassing the northern state of Durango as the main source of heroin, and succeeded, accounting for $70 \%$ of heroin produced in Mexico (Kyle 2015). This output is aimed primarily at markets in the United States and Canada, and secondarily at the Mexican market, consisting not only of Mexicans but also gringo tourists. Guerrero is also a hub of the so-called Pacific Route which the transnational DTOs regard as a strategic path 'not only [of cocaine] to North America, but also, for the arrival of raw materials for the production of cocaine and for the industry of synthetic drugs' (Pérez 2016: 136) (Saviano 2015; Pérez 2016; Rosen and Zepeda 2016).

Following Krauthausen and Sarmiento (1991) about the logic behind the violent conduct of DTOs, the possession of territory is vital for DTOs to control areas for the production, storage, sales, and distribution of raw materials. In an environment of illegality, this often leads to violent disputes and the exercise of control over local populations, via coercion as well as patronage, in order to retain the conquered territories (Rodrigues and Labate 2016; Rodrigues 2017). In this respect, Krauthausen's and Sarmiento's insights into the political economy of drug trafficking in the Americas support our analysis of the political interactions that provided borders which, aggravated by Acapulco's role in the America's political economy and geopolitics of drug trafficking, led to the city becoming an epitome of contemporary (in)security in urban zones in the region.

\section{Contemporary (in)security dynamics in Acapulco's urban zones}

\section{The political factor}

Based on Krauthausen's and Sarmiento's framework for systematising drug trafficking operations in the Americas, the contemporary (in)security dynamics in urban areas will be examined via the politics among the central role players, namely the DTOs themselves. Krauthausen and Sarmiento (1991) recognise three operational levels in drug trafficking in the Americas. The first is the production level, where many illegal actors undertake the production of raw materials (i.e., coca leaves or poppy) and their initial chemical transformations (i.e., into the pasta base for cocaine, or opium latex). The second is the oligopoly level, where a small number of DTOs with major resources (large sums of money, institutional penetration, chemical expertise, political influence, and contact with international logistical networks), refine the raw drugs into more valuable forms (i.e., cocaine and heroin). The authors argue that Colombian DTOs, such as the Medellín and Cali cartels, never reached the status of a 'cartel' in its economic definition of a market in which a small number of actors control the production and distribution of a given product, in a way 
that divides markets, eliminates concurrents, and establishes a retail price for consumers. Instead, the notorious Colombian DTOs of the 1980s operated as oligopolies, without explicit or durable centralisation, which led to agreements among them on how to secure their operations in Colombia as well as their transnational connections with major wholesale DTOs, such as the Italian mafia (Krauthausen and Sarmiento 1991: 35-53).

The third dimension of this intercontinental economy is the retail level, where local DTOs buy 'pure drugs' from the logistics DTOs and then prepare them for retail sales (usually by adulterating them to increase their volume). These groups control the urban areas of the new metropolitan involution, and tend towards fierce territorial conflicts among themselves aimed at securing their exclusive territories and preserving the confidence of the wholesale DTOs. Krauthausen and Sarmiento (1991) maintain that the first and third phases are defined by competition, as many actors fight over a very profitable business. They argue that competition over illegal markets tends to be violent, since there is no legitimate actor capable of persuading, inducing, or coercing the parties involved to maintain peace. The second phase tends to be less violent. Given a (subtle) balance among a smaller number of DTOs capable of penetrating, corrupting, and controlling state apparatuses and some sectors of the formal economy, the major players act as kingpins, as successful and feared business people, who prefer to negotiate and to corrupt rather than to fight each other.

Until the 2000s, Mexican DTOs occupied a secondary position in the political economy of drug trafficking in the Americas, behind the Colombian cartels. Until then, Mexican DTOs were also less fragmented, while dedicated to the production of heroin and marijuana for a limited share of the US market, mainly smuggling Colombian cocaine into the United States. Nevertheless, business was on the rise, and Colombia's dominant position in this economy was about to change.

From 2005 onwards, various DTOs (CIDA, La Barredora, Guerrero Seguro, and others) in the AMZ began to fight each other, counting on unstable alliances with two rival 'cartels': Los Zetas and the Sinaloa cartel (Revelo 2011; Kyle 2015). They were competing over control of Guerrero's smuggling routes and heroin output (Kyle 2015: 18). By then, these DTOs were significantly fragmented, while, in 2012, La Barredora is said to have disappeared from the streets of AMZ (Kyle 2015). Since 2010, Guerrero has witnessed the emergence of a 'multitude of [drug-related] criminal groups with unstable internal and external relations' (Kyle 2015: 22). The volatility of these organisations has altered the previous established illegal connections with local politicians, entrepreneurs, economic elites, land owners, local populations, and local police forces. The open competition among small and unstable DTOs has intensified the violent dispute over territory as well as social, political and economic influence. This situation has become even more complex and violent since federal forces began to combat the DTOs in Guerrero, focusing on Acapulco.

Based on Krauthausen's and Sarmiento's framework, Mexico can be understood as a combination of the competitive and oligopolistic levels. There are major DTOs, such as the Gulf cartel, the Sinaloa cartel, Los Zetas and the La Familia Michoacana, which rule vast urban and rural areas while controlling the production of raw materials as well as 
refined drugs. Furthermore, these organisations have the capacity to corrupt politicians, business people, police, and military officers. They also control crucial logistical networks in South America, the Caribbean, Asia, and the United States. Mexico's proximity to the world's biggest drug market feeds a non-stop scenario of competition. Therefore, the operation of Mexican DTOs can be viewed as a hybrid oligopolistic-competitive model comprising constant confrontation, fleeting alliances, struggles to survive, and efforts to expand illegal activities.

Table 2 corroborates Krauthausen and Sarmiento's claims that competition among many actors fighting over highly profitable illegal business operations tend to generate high levels of violence. In the case of the AMZ, Guerrero's only metropolitan area, this translated into an increase in homicides, concentrated in the spaces of the new metropolitan involution, the marginalised urban areas outside the spaces of historical income concentration. Table 2 reflects the growth in homicides that turned Acapulco into one of the five most violent cities in the world.

Table 2: Violent deaths in Guerrero by month, 2010 and 2011

\begin{tabular}{lcl}
\hline Month & $\mathbf{2 0 1 0}$ & $\mathbf{2 0 1 1}$ \\
\hline January & 41 & 86 \\
February & 47 & 100 \\
March & 88 & 137 \\
April & 42 & 105 \\
May & 53 & 154 \\
June & 60 & 153 \\
July & 41 & 175 \\
August & 77 & 213 \\
September & 64 & 161 \\
October & 93 & 158 \\
November & 100 & 115 \\
December & 109 & 98 \\
\hline
\end{tabular}

Source: INEGI.

Given that 2010-2011 marks a crucial period in which the fragmentation of Acapulco's DTOs triggered more vicious competition among smaller organisations, and the growth in population densities in the AMZ, it becomes clear why homicides increased, and how the creation of fresh boundaries by the political apparatus in the course of the 'war against drugs' interacted with the complex economic and geographical process of otherness in the city of Acapulco. 


\section{The Mexican war on drugs, militarisation, and Acapulco}

\section{A brief contextualisation of the war on drugs in Mexico after the 1990s}

In the 1990s, due to increased US surveillance, the Caribbean drug smuggling route from the Americas to the United States became more problematic, thus forcing kingpins such as Colombia's Pablo Escobar, the leader of the Medellín cartel, to develop alternatives. As a result, Mexico returned to the core of the political economy and geopolitics of drug trafficking in the Americas.

The balloon effect is at the core of the shifting priorities in the international political economy of drug trafficking at the start of the $21^{\text {st }}$ century. In December 2006, when Calderón took office in Mexico, local DTOs controlled nearly $90 \%$ of all cocaine smuggled into the United States, producing substantial amounts of heroin and synthetic drugs (Rosen and Zepeda 2006: 22). When Calderón's electoral victory was tainted by allegations of fraud, he managed to boost his campaign numbers by declaring 'total war' against DTOs.

Nevertheless, drug trafficking and violence skyrocketed during his administration (Carpenter 2012; Grillo 2012), with organised crime groups fighting among each other over territory and drug routes (Watt and Zepeda 2012; Jones 2016). A common belief that police forces were corrupt or prone to corruption bolstered Calderón's decision to deploy the military instead of the police, which demanded changes to the constitution. In 2007, Calderón and George W Bush signed the Mérida Initiative, a bilateral agreement to fight drug trafficking, which was quickly compared to Plan Colombia, especially since it 'allocated the vast majority of the resources to hard components [military equipment and training]' (Rosen and Zepeda 2016: 20). The key modus operandi was to equip the military to intervene in domestic law enforcement and security (Benítez Manaut 2010; Anaya 2014).

After becoming president in 2012, Enrique Peña Nieto promised to revamp Mexico's security strategy. He distinguished himself from the previous government by focusing less on the discourse of the drug war and more on social reform - a strategy that has not been very successful. Indeed, Semple (2016) has argued that '[ $t$ ]he surge in violence around Mexico reflects an increasingly volatile criminal landscape, and the limitations of North America's counternarcotics strategy'. This may help to explain why politicians seek to portray the escalating violence in a certain way, especially following the escape of the notorious drug lord Joaquín 'El Chapo' Guzmán from a federal prison in July 2015 as well as the assassination of 43 students at a teacher's college in Ayotzinapa, Guerrero, in September 2014, with the complicity of local authorities, including the police (Boullosa and Wallace 2015; Stone 2016; Gallegos 2017). The latter incident drew international attention to the state of Guerrero and its increasing levels of urban violence.

\section{Militarisation and practices of urban security}

In the $20^{\text {th }}$ century, 'war re-entered the city' in tandem with massively increased levels of urbanisation worldwide but especially in post-colonial regions, a trend that has created 
new zones of involution and enemy formation, of visible and invisible boundaries within urban spaces (Graham 2010: 49). Indeed, Graham has described the current phase of the relationship between warfare and cities as the 'new urban militarism' (2010: 121) He identifies a trend to 'extend and revivify the urban militarisation, securitisation, ${ }^{2}$ Manichean thinking, and fear-mongering that were a central feature of the Cold War but also of earlier wars' (Graham 2010: 121).

This 'new militarism' reclaims features of historical processes of militarisation such as 'the social construction of a conceptual division between the inside and the outside of a nation or other geographic area, and the orchestrated demonisation of enemies and enemy places beyond the boundaries of inside' (Graham 2010: 122). Given this, he defines militarisation as a 'complex and multidimensional process' involving:

the normalisation of military paradigms of thought, action and policy; aggressive attempts to discipline bodies, places and identities deemed not to benefit masculinised (and interconnected) notions of nation, citizenship or body; and the deployment of a wide-range propaganda which romanticises or sanitises violence as a means of righteous revenge (Graham 2010: 122).

Beyond notions developed by Zaverucha (2000) and Bagley (1993), who understood militarisation as the presence of military troops in policing activities, the nomination of high-ranking military officers for key public safety positions, and the formation of special military battalions to fight criminal organisations, Graham's 'new military urbanism' is a comprehensive concept that recognises the tangible and intangible features of militarisation. Additionally, Graham's notion allows analyses of how a set of technologies originally developed for military purposes, such as GPS and video surveillance, has been applied for 'civilian' purposes, recalling Foucault's reflection on the 'society of disciplines' that, from the late $18^{\text {th }}$ to the mid- $20^{\text {th }}$ century, aimed at the production of docile and useful bodies within institutions such as prisons and factories (Foucault 1995).

This notion of society was gradually superseded by Deleuze's (1992) idea of 'societies of control' in which electronic monitoring and open-air surveillance have introduced new forms of social control. In this context, militarisation is not only related to the use of force, but also to a particular mindset, distinguishable within public security policies as well as among civil society - as demonstrated by the diffusion of restrained urban areas, walls and electronic monitoring, and the widespread use of private security companies for personal and property protection.

Among the most important features of this new urban militarism are the blurring of the 'traditional military imperative of war, external to the state, and those of the policing internal to it' (Graham 2010: 137-138). The increasing conflation of public safety, national security and international security is one of the most intensively discussed issues in contemporary IR literature (Gros 2010; Kaldor 2012; Bigo 2002; Feldman 2004; Rodrigues forthcoming). In general, this literature addresses what Neocleous calls 'the militarisation of policing and the policialisation of the military' (2014: 09-10). The identification, by politicians and others, of transnational non-state actors, such as terrorist organisations 
and DTOs, as major threats to security reinforces the articulation between internal and external security practices, which further blurs the separation of the national and the international, the police and the military.

Neocleous (2014) develops a broader definition of security, leading him to Foucault's reflections on the genealogy of the concept of police, linked to the emergence of modern European states. Foucault (2009) claimed that when the first modern states were in the process of formation, the predominant notion of 'police' among the Absolutist princes was related to a complex set of royal decisions and policies aimed at controlling the economy, or the total circulation of goods and people within the territory in question and between it and other countries, and the territorialisation of subjects and their occupations in the name of the splendour and wealth of the kingdom. According to Foucault (2009), the contemporary notion of police as a repressive law enforcement state agency emerged in the late $18^{\text {th }}$ century, after the liberal criticism of its centralised economic control by the state.

However, the modern tradition of political philosophy established a definition of the state as the institution legitimised by a social contract that restricted 'peace' within national borders. Neocleous (2014) underscores the abstraction of social contract theory, unveiling the production of legitimacy through a violent history of state formation marked by military victories of certain groups over others. Politics and the state, then, would be pervaded by conflict, since governmental practices comprise complex tactics seeking the production of certain social behaviours, mindsets, discipline, and order. In this sense, the political is not synonymous with peace but with pacification (i.e., the imposition of someone's order over a territory and a population) (Neocleous 2014; Rodrigues forthcoming).

As noted by RBJ Walker (1993), the production of modern political thought involved the construction of an internal order corresponding with 'peace' in contrast with an external environment of chaos and anarchy: a peaceful 'inside' threatened by a violent 'outside?. This inside/outside duality is crucial for defining the 'national self' in the face of an external (and potentially threatening) 'otherness', which is basically the transposition of the modern concept of subjectivity based on a remote Western Manichaean tradition built upon divisions between good and evil, peace and war, salvation and damnation.

The contemporary emergence of transnational non-state actors sheds light on the permanent 'state of violence' (Gros 2010) within, across and outside state borders, providing the current dynamics of violence in which the city is the main battlefield, and unveiling the perennial animosity of a process of otherness within the borders of the nation-state. Governments, then, become entities whose responsibility includes 'to separate people and circulations deemed risky or malign [for the flows of global capitalism] from those deemed risk-free or worthy of protection' (Graham 2010: 158).

\section{The militarisation of the war on drugs in Acapulco}

The methodological decision referred to earlier to stick to the CCSPJP and INEGI data has political implications. Bearing in mind that the Homicide Monitor data on Mexico is biased by the interests of agents directly involved in the decision to militarise the campaign 
against drug trafficking in urban areas, it is not hard to infer why it opts to report records of judicial inquiries, which tends to underplay the number of homicides, since there are cases in which one inquiry accounts for several homicides - a particular flaw in the case of the post-militarisation AMZ - instead of establishing how many homicides occurred in the course of a given incident or investigation.

Since the militarisation of the fight against drug trafficking in Acapulco (in October 2011), the Homicide Monitor has provided the following data:

Table 3: Homicide Monitor data for the City of Acapulco, 2011-2016

\begin{tabular}{llll}
\hline Year & Number of homicides & Population & Rate per $\mathbf{1 0 0} \mathbf{0 0 0}$ inhabitants \\
\hline 2011 & 1008 & 813443 & 123,9 \\
2012 & 1170 & 822422 & 142,3 \\
2013 & 883 & 830309 & 106,3 \\
2014 & 590 & 837271 & 70,5 \\
2015 & 902 & 843413 & 107 \\
2016 & 918 & 838841 & 108,2 \\
\hline
\end{tabular}

Source: Homicide Monitor.

The contrast between Table 3 and Table 1 is revealing.

Table 4: Comparison of average and median homicide rates

\begin{tabular}{lll}
\hline & CCSPJP & Homicide Monitor \\
\hline Average homicide rates & 117,62 & 109,7 \\
Median homicide rates & 108,48 & 88,4 \\
(Average - Median) & 9,14 & 21,3 \\
\hline
\end{tabular}

Source: Compiled by the authors from CCSPJP and Homicide Monitor data.

The difference between the average homicide rate is relatively slight when compared to the differences between the medians. This is alarming, as it shows that the samples differ significantly in terms of the concentration of homicide rates per year. In both samples, homicide rates decrease from 2011 until 2016, yet the level of decrease is strikingly different. While CCSPJP's homicide rates tend to stabilise following a slight decrease after the militarisation of Acapulco's campaign against drug trafficking, Table 3 shows that the lowest homicide rates are concentrated in the years following militarisation.

If it is in the interests of the Igarapé Institute's data sources to present optimistic data about the militarisation of the war on drugs in urban areas, be it for electoral, financial, institutional or other reasons, it is indeed alarming that it chose a method that is bound to downplay the numbers of homicides, especially since a state agency, which is meant to be less motivated to downplay or overplay the same figures, is the source of the CCSPJP sample. It is possible to infer that public agencies which are subject to electoral processes and are responsible for negotiating with foreign role players about issues surrounding 
drug trafficking in Mexico are more prone to maximising the positive impacts of militarisation on homicide rates in urban areas than public agents who are regionally bound, avoiding at least some of the local pressures to portray data in certain ways, besides being disconnected from the decision-making process of militarisation.

Furthermore, while the internal variations in homicide rates in 2011 and 2012 are relatively similar, there are significant differences in the rates of decrease in 2013. Since the Homicide Monitor sample focuses on opened investigations, it is possible to infer that, following the early years of militarisation, when homicide rates increased with the entrance of yet another armed actor in the urban violence surrounding drug trafficking in Acapulco, this became normalised under the paradigm of a new urban militarism (Graham 2010). In the case of the Homicide Monitor sample, this normalisation follows a significant drop in homicide rates. Given that the CCSPJP rates are significantly higher, this points to a concentration of violent incidents, which in both cases, albeit to different degrees, can be deemed a result of normalisation. Figures 1 and 2 corroborate this, as they depict a decrease in violent incidents throughout the AMZ as well as a concentration of these incidents in areas of metropolitan involution.

As Graham (2010) contends, the new urban militarism entails the deployment of wide-ranging propaganda that romanticises and/or sanitises the massive use of power against a particular grouping. When this propaganda emphasises the reduction of violence through the legitimate use of force, it tends to disguise what Neocleous (2014) and Rodrigues (forthcoming) characterise as a desire for social revenge, especially in a situation in which the inherent tendency of the social contract to legitimise the violent process of silencing and targeting certain groups of people is increasingly revealed. The Igarapé Institute's use of Sistema data, especially in the light of the former's credibility in the media, could then be interpreted as propaganda which seeks to depict liberal patterns of efficiency, through which the state is successfully disciplining and controlling the urban areas of the new metropolitan involution.

When the Igarapé Institute's data and methods are presented in its user-friendly, 3D Homicide Monitor, in contrast with CCSPJP's and INEGI's conventional texts and more technical approaches, the Institute becomes a tool in the transition of a society of disciplines to a society of control, by normalising - and technically glamourising - death tolls in urban regions objectified by the geographic, economic, and political boundaries in the city of Acapulco. Also, when this data glorifies the tactics of discipline and control that further diffuse the existence of constricted areas within metropolitan zones, it lends credibility as well as efficiency to the normalisation of segregation through other technological means, such as walls, electronic monitoring, and private security companies.

In contrast with the Homicide Monitor, the CCSPJP data does not provide tools for deepening the inside-outside logics transported into Acapulco through the geographic, political and economic processes of 'otherness'. If the normalisation of the new urban militarism means the assimilation of military paradigms of thought, action, and policy into the city's daily life, the slight decrease in homicide rates in Acapulco following Operation Guerrero Seguro in the CCSPJP data could be interpreted as optimistic, vis-à-vis an enemy too complex to wane so rapidly, or as a debacle, as it would show that the state, 
with all its lethal power, and backed up by a superpower, the United States, has failed to re-establish the pre-2011 status quo.

The importance of the CCSPJP and INEGI data in illustrating the processes of 'otherness' in these involuted areas cannot be overstated. The visible and invisible boundaries created by geographic, political, and economic processes of 'otherness' are the dependent variables that explain the outburst of violence in the AMZ through the worsening of the political economy and the geopolitics of drug trafficking in the Americas, as well as through practices of militarisation. Since processes of otherness are deeply entrenched in perceptions of the other, the data adds to a set of beliefs that tends to vary according to the identity of the individual or group.

In a city, these individuals and groups are generally bound to certain territories, demarcated by spatial divisions that are enforced and reinforced by all the parties involved in drug trafficking conflicts. Even though, in the $21^{\text {st }}$ century, social media can help to overcome social segregation, practices of militarisation still rely on physical borders to highlight otherness, as restrained urban areas, both for their potential threat and for their potential as targets, not rarely portray walls - some made of barricades; others, of glass and surveillance - marking down differences and limitations, friendship and animosity, inside and outside.

Maps provide a helpful visual representation of the territorial dynamics of a given phenomenon. In this instance, Figures 1 and 2 are particularly relevant as territoriality is intrinsic to geography, economics, and geopolitics. Figure 1 depicts criminal activity in the AMZ in July 2011, a few months before Operation Guerrero Seguro began.

Figure 1: Criminal Activity in the AMZ, July 2011

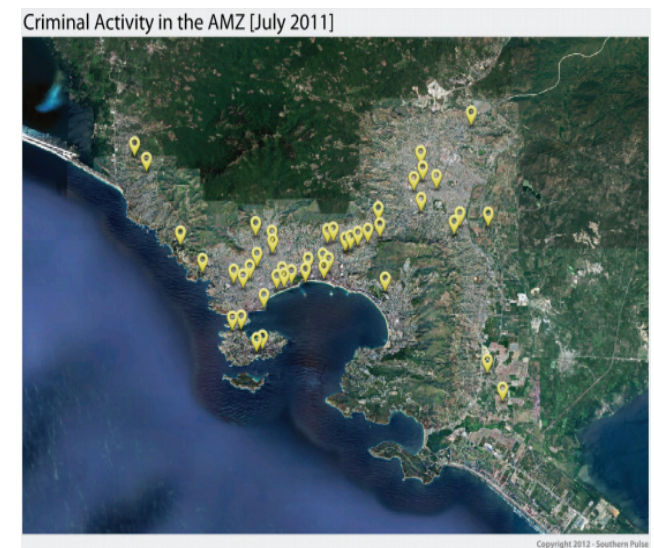

Source: Southern Pulse (2012: 10).

The hotels and other properties of 1950s and 1960s fame are on the right side of the bay, where tourist activity and wealthy residential areas are still concentrated. The pins are concentrated in the areas of metropolitan involution, and helped to make Acapulco the second most violent city in the world in that year.

In October 2011, the militarisation of the campaign against drug trafficking, acommon trait of the war on drugs in the Americas, was no different in Acapulco, and 
was promoted as part of the bilateral co-operation between the United States and Mexico through the Mérida Initiative. Implemented from October 2011 onwards by federal police and Mexican military forces in the AMZ, Operation Guerrero Seguro brought back the counter-narco-dollars to the state. By then, there was a quasi-oligopoly in the AMZ due to the dominant role of two local DTOs - La Barredora and the Independent Cartel of Acapulco - operating on Krauthausen's and Sarmiento's supposedly less violent second level. The remnants of the Beltrán Leyva DTO were trying to survive, while the Jalisco New Generation - based in the neighbouring state of Jalisco - were planning incursions into Acapulco due to its proximity to Puerto Vallarta (one of the most important ports for Latin American trade with Asia), American spring breakers, as well as Mexican tourists.

As Figure 2 shows, the federal police and military forces successfully reduced the size of the area of involution in which these crimes against life were concentrated. However, the number of casualties only stabilised in relation to the peak months preceding the operation. Therefore, it could be argued that although DTOs, the police, and the military did not confront each other over as large an area, or as frequently, the level of violence and perhaps of weapons sophistication (and mortality), tended to increase.

Figure 2 depicts criminal activity in the AMZ in January, February, March, and April 2012. It depicts a phenomenon similar to other urban zones in the Americas following military deployment in so-called slums, namely the spread of violence to Acapulco's traditional tourist area. The intangible geographic, political and economic boundaries between these areas and those of metropolitan involution explain why the spread of crime into these elite neighbourhoods are crimes against property rather than crimes against life. These dynamics represent an institutionalised, visible boundary separating the subject from the object, reifying the inhabitants and territories of involuted metropolitan regions whose lives then do not matter, at least not as much as those of the elites and their possessions.

Figure 2: Criminal activity in the AMZ (January, February, March, and April 2012)

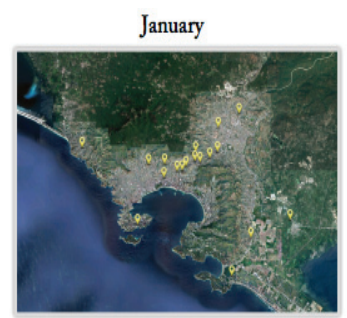

March

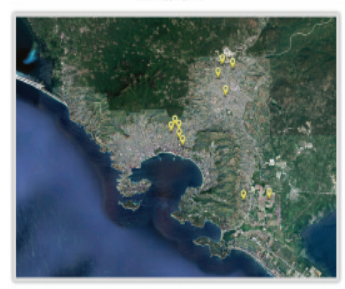

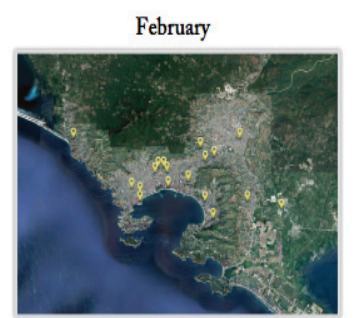

April

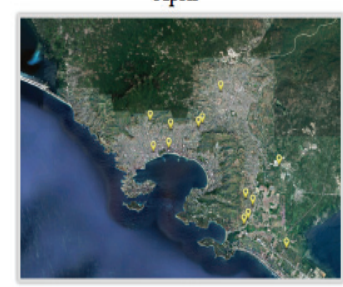

Source: Southern Pulse (2012: 10). 
Even though 'inter-cartel' violence was already evident in 2010, it was only when these figures were associated with the militarisation of Acapulco's strategies against drug trafficking that the city entered the ranking of the 50 most violent cities in the world, in a context that already tended to escalate following Calderón's militarisation of Mexico's war on drugs. Due to these policies, violence increased in urban centres that were previously secondary to the political economy and the geopolitics of drug trafficking. Moreover, the process of otherness that had developed visible and intangible social boundaries within these areas guaranteed fertile grounds for DTOs, as well as for the militarisation of the campaign against them.

There are two possible explanations for the high levels of violence following the deployment of the federal police and military forces. One is that both forces tend to elevate the deadly range of weaponry used by all sides of the conflict. Another is that these forces simply act as peacekeepers, with a mandate to combat people on all sides of the dispute, which leads to increases in homicides.

Moreover, the militarisation of Mexico's war on drugs has tended to force DTOs to expand or displace their activities to other regions. In line with this, the influence of DTOs from other Mexican states in Acapulco also increased, adding more complexity and violence to the regional dynamics. According to Kyle (2015: 21), 'the violence was distributed throughout [Acapulco], but was especially common in the sprawling working-class neighbourhoods of Colonias Zapata, Renacimiento, Jardines, and Coloso.' In other words, violence related to drug trafficking was concentrated in areas of Acapulco that are home to representatives of the outside, the objectified side of the process of otherness: those who inhabit areas of the new urban involution.

The deployment of the federal police and military forces did not avert the proliferation of struggles among DTOs, or reverse the problem of high homicide rates by containing the violence in certain geographic areas. The federal police and armed forces simply began to play a symbolic role in the social imaginary, addressing the fears harboured by one group about another.

\section{Final remarks}

This hybridity of Mexico's landscape, one of oligopoly and competition among DTOs, has its pinnacle in the city of Acapulco. While analysts tend to concentrate on cities located on the US border, Acapulco's current status as the deadliest city in Mexico provides grounds for an archetype of the urban dynamics of drug trafficking in the Americas. Through a process of 'otherness' that breeds visible and invisible boundaries separating subject from object, inside from outside, friend from enemy - a rationale traditionally applied in interstate relations - the new metropolitan involution, economic inequalities embedded in segregated spaces within the AMZ, and political struggles, especially among DTOs, are central to this.

The potential violence of the process of otherness is aggravated in Acapulco by its place in the political economy and geopolitics of drug trafficking in the Americas, cycles and fluxes that add up to the animosity of the otherness constructed geographically, eco- 
nomically, and politically in the AMZ. When, in October 2011, urban militarisation was added to these variables, Acapulco entered the ranks of the 50 most violent cities in the world.

Debates about the methods used to compile data about homicides in Acapulco in particular and Mexico in general have led to findings about the political attitudes inherent to portraying the data of various institutions. It has also allowed us to trace certain spatial trends that feed into the production of new boundaries in the city.

The real estate market, for example, has benefited from the territorial concentration of violent incidents following the militarisation of the war on drugs in Acapulco, since it has profited from the gentrification of formerly violent regions (Paley 2014: 163). Among others pointed out in this study, this trend provides a clue for researches who seek to trace the effects of the militarisation of the campaign against drug trafficking in urban spaces.

\section{Notes}

1 From now on, the phrase 'war on drugs' wil be used without quotation marks, not because of the authors' personal opinions about this matter, but for reasons of practicality (Labrousse and Laniel 2001; Marcy 2010; Nixon 1971; Rodrigues and Labate 2016: 11).

2 The concept of 'securitisation' has gained currency in international studies since the 1990s, when it was proposed by members of the Copenhagen School. Despite later revisions and updates, it can be summarised as the process that causes a given 'public issue' to be classified as 'an existential threat, requiring emergency measures and justifying actions outside the normal bounds of political procedure' (Buzan, Wæver and De Wilde 1998: 24).

\section{References}

Anaya Muñoz, Alejandro. 2014. Violaciones a los derechos humanos en el marco de la estrategia militarizada de lucha contra el narcotráfico en México (2007-2012). Aguascalientes: Cuadernos de Trabajo del Monitor de Programa de Política de Drogas del CIDE Región Centro.

Anselin, Luc, Jacqueline Cohen, David Cook, Wilpen Gorr and George Tita. 2000. 'Spatial analyses of crime.' In David Duffee (ed), Criminal Justice 2000: Volume 4. Measurement and Analysis of Crime and Justice. Washington, DC: National Institute of Justice, pp. 213-262.

Ashworth, Gregory J. 1991. War and the City. New York/London: Routledge.

Astorga, Luis. 2015. Drogas sin Fronteras. Mexico: Del Bolsillo.

Bagley, Bruce. 1993. 'Los mitos de la militarización: las fuerzas armadas en la guerra contra las drogas'. In Peter H Smith (ed), El combate a las drogas en América. México: Fondo de Cultura Económica, pp. 181-206.

Benítez Manaut. Raúl. 2010. 'México 2010. Crimen organizado, seguridad nacional y geopolítica', In Raúl Benítez Manaut (ed), Crimen organizado e Iniciativa Mérida en las relaciones México-Estados Unidos. México DF: CASEDE, pp. 9-30.

Bigo, Didier. 2002. 'Guerres, conflits, transnational et territoire (Partie 1)'. Cultures \& Conflits, 21(21): 01-10.

Bursik, Robert J and Harold G Grasmick. 1993. 'Economic Deprivation and Neighborhood Crime Rates, 1960-1980'. Law \& Society Review, 27 (2): 263-83. 
Buzan, Barry, Ole Wæver and Jaap De Wilde. 1998. Security: a new framework for analysis. Boulder/ London: Lynne Rienner Publishers.

Carpenter, Ted Galen. 2012. The Fire Next Door: Mexico's Drug Violence and the Danger to America. Washington, D.C.: CATO Institute.

Citizen Council for Public Security and Criminal Justice of Mexico (CCSPJP). 2017. Metodología del ranking (2016) de las 50 ciudades más violentas del mundo. At http://www.seguridadjusticiaypaz.org.mx/biblioteca/prensa/send/6-prensa/239-las-50-ciudades-mas-violentas-del-mundo-2016-metodologia [Accessed on 4 July 2017].

Corva, Dominic. 2009. 'Biopower and the Militarisation of the Police Function'. ACME: An International E-Journal for Critical Geographies, 8(2): 162-175.

Deleuze, Gilles. 1992. 'Postscript on the Societies of Control'. October, 59: 3-7.

Esquivel, J Jesús. 2013. La DEA en México. Mexico: Grijalbo.

Feldman, Allen. 2004. 'Securocratic Wars of Public Safety'. Interventions: International Journal of Post Colonial Studies, 6(3): 330-350.

Freeman, Laurie and Jorge Luis Sierra 2005. 'México: la trampa de la militarización', In Coletta Youngers and Eileen Rosin (eds), Drogas y Democracia en América Latina: el impacto de la política de Estados Unidos. Buenos Aires: Biblos, pp. 325-371.

Foucault, Michel. 1995. Discipline and Punish: the Birth of Prison. Transl. Alan Sheridan. New York: Vintage Books.

2009. Security, Territory, Population. Lectures at the Collège de France 1977-78. Editor Michel Senellart; Transl. Graham Burchell. New York: Picador.

Gallegos, Zorayda, 2017. 'With “El Chapo” Guzmán gone, war erupts in Mexican state of Sinaloa', El País, March 7, p. 10A.

Giddens, Anthony. 1985. Nation-state and Violence (Vol. 1). Berkley/Los Angeles: University of California Press.

Goldstone, Jack A. 2002. 'Population and Security: How Demographic Change Can Lead to Violent Conflict'. Journal of International Affairs, 56(1): 3-21.

Graham, Stephen. 2004. 'Introduction: Cities, Warfare, and States of Emergency'. In Stephen Graham (ed), Cities, War and Terrorism: towards an urban geopolitics. Malden: Blackwell Publishing, pp. 01-30. 2010. Cities under Siege: the new military urbanism. London/New York: Verso Books.

Grillo, Ioan. 2012. El Narco: Inside Mexico’s Criminal Insurgency. New York: Bloomsbury Press.

Gros, Frédéric. 2010. States of Violence: an essay on the end of war. London/New York/Calcuta: Seagull Books.

Gutiérrez, Alejandro. 2007. Narcotráfico: el gran desafío de Calderón. Mexico: Temas de Hoy.

Heinle, Kimberly, Cory Molzahn and David A Shirk. 2015. Drug Violence in Mexico: Data and Analysis through 2014. Special Report, Justice of Mexico Project, Department of Political Science International Relations. San Diego: University of San Diego.

Jones, Nathan P. 2016. Mexico's Illicit Drug Networks and the State Reaction. Washington D.C.: Georgetown University Press.

Kaldor, Mary. 2012. New and Old Wars: Organised Violence in a Global Era (3rd edition). Cambridge: Polity Press. 
Keegan, John. 1993. A History of Warfare. New York: Alfred A. Knopf

Krauthausen, Ciro and Luis Sarmiento. 1991. Coca \& Cocaína: un mercado ilegal por dentro. Bogotá: Tercer Mundo.

Kyle, Chris. 2015. Building Resilient Communities in Mexico: Civic Responses to Crime and Violence. Washington/San Diego: Woodrow Wilson Centre / University of San Diego.

Labrousse, Alain and Laurent Laniel. 2001. The World Geopolitics of Drugs. Dordrecht: Springer.

Langton, Jerry. 2013. Gangland: the rise of the Mexican cartels from El Paso to Vancouver. Ottawa: HarperCollins.

Lupsha, Peter A. 1981. 'Drug Trafficking: Mexico and Colombia in Comparative Perspective'. Journal of International Affairs, 35(1): 95-115.

Lyon, David. 2004. 'Technology vs. “Terrorism”: circuits of city surveillance since September 11, 2001'. In Stephen Graham (ed), Cities, War and Terrorism: towards an urban geopolitics. Malden: Blackwell Publishing, pp. 297-311.

Marcy, William L. 2010. The politics of cocaine: how the U.S. foreign policy has created a thriving drug industry in Central and South America. Chicago: Lawrence Hill Books.

Mathieu, Hans and Saruy Tolosa (eds). 2014. Violencia Urbana: radiografía de una región. Bogotá: Aguilar/FES.

Neocleous. Mark. 2014. War Power, Police Power. Oxford: Oxford University Press.

Paley, Dawn. 2014. Drug War Capitalism. Oakland/Edinburgh: AK Press.

Pérez, Ana Lilia. 2014. Mares de Cocaína: las rutas náuticas del narcotráfico. Mexico: Grijabo-Proceso.

Plane, David A. 2004. 'The Post-Trewartha Boom: The Rise of Demographics and Applied Population Geography'. Population, Space and Place, 10(4): 285-288.

Ravelo, Ricardo. 2011. El narco en México: historia e historias de una guerra. Mexico: Grijalbo.

Rodrigues, Thiago. 2017. Política e drogas nas Américas: uma genealogia do narcotráfico. São Paulo: Desatino.

Forthcoming. Politics is Warfare: Agonism and International Relations. Edinburgh /Oakland/Baltimore: AK Press.

Rodrigues, Thiago and Beatriz Caiuby Labate. 2016. 'Prohibition and the War on Drugs in the Americas: an analytical approach'. In Beatriz Caiuby Labate, Clancy Cavnar and Thiago Rodrigues (eds), Drug Policies and the Politics of Drugs in the Americas. Cham: Springer, pp. 11-32.

Rosen, Jonathan and Roberto Zepeda. 2016. Organised Crime, Drug Trafficking, and Violence in Mexico: the transition from Felipe Calderón to Enrique Peña Nieto. Lanham: Lexington Books.

Sabet, Daniel M. 2012. Police Reform in Mexico: informal politics and the challenge of institutional change. Stanford: Stanford University Press.

Santana, Adalberto. 2004. El narcotráfico en América Latina. México: Siglo Veintiuno.

Santos, Milton. 1993. A urbanização brasileira. São Paulo: Hucitec.

Saviano, Roberto. 2015. Zero, Zero, Zero. New York: Penguin Random House.

Semple, Kirk. 2016. 'Mexico grapples with a surge in violence. The New York Times, December 13.

Shawn, Martin. 2004. 'New Wars of the City: Relationships of "Urbicide" and "Genocide"' In Stephen Graham (ed), Cities, War and Terrorism: towards an urban geopolitics. Malden: Blackwell Publishing, pp. 141-153. 
Shirk, David. A. 2010. Drug Violence in Mexico: Data and Analysis from 2001-2009. San Diego: Trans-Border Institute: Joan B Kroc School of Peace Studies.

Southern Pulse. 2012. Acapulco Criminal Environment. At www.southernpulse.com [accessed on 26 April 2017].

Stone, Hannah. 2014. 'The Disappeared of Iguala, Mexico: A Crime Foretold'. InSight Crime, November 20, pp. 13-16.

The Economist. 2017. 'The World's Most Dangerous Cities: the cities with the highest homicide rates are once again nearly all in Latin America. At http://www.economist.com/blogs/graphicdetail/2017/03/daily-chart-23 [Acessed on 20 April 2017].

Tilly, Charles. 1990. Capital, Capital, and European States - AD 990-1990. Cambridge: Basil Blackwell.

Walker, RBJ. 1993. Inside/Outside: international relations as political theory. Cambridge: Cambridge University Press.

Zaverucha, Jorge. 2000. 'Fragile Democracy and the Militarisation of Public Safety in Brazil.' Latin American Perspectives, 27(3): 8-31.

\section{About the authors}

Thiago Rodrigues is Head of Department in the Institute for Strategic Studies (INEST) at Fluminense Federal University (UFF) in Brazil; Communications Director of the Global South Caucus (International Studies Association, ISA); and Director of Institutional Relations of the Brazilian Association for Defence Studies (ABED). He specialises in the study of drug trafficking and International Relations theory. He is also Assistant Editor of the Oxford academic journal International Political Sociology, and co-editor of the books Drug Policies and the Politics of Drugs in the Americas (Springer, 2016), and Drogas, Politica $y$ Sociedad en América Latina y Caribe (CIDE, 2015), among others.

Mariana Kalil is a PhD candidate in International Relations at the University of Brasilia (UnB), Brazil. She is Vice-Chair of the Global South Caucus, Grad Student Representative in the Theory Section of the International Studies Association (ISA), and integrates the Communications Team of the Oxford academic journal International Political Sociology. She is also a lecturer (Professor in Collaboration) in International Relations at the Institute for Strategic Studies (INEST/UFF), and a former temporary lecturer (Substitute Professor) in the Department of Defence and International Strategic Logistics (DGEI/ UFRJ). She is the author of 'Brazil's Rise in the $21^{\text {st }}$ Century: Ambitions and Difficulties', in Jacqueline Braveboy-Wagner (ed), Diplomatic Strategies of Nations in the Global South: The Search for Leadership (Palgrave, 2016), among others.

Roberto Zepeda is a researcher at the Center for Research on North America (CISAN) at the National Autonomous University of Mexico (UNAM), and former Research Professor at the Institute of International Studies at the Universidad del Mar-Huatulco, Mexico. His publications include 'Collateral Effects of Migration in the Americas: Security Implica- 
tions', in Bruce M Bagley, Jonathan D Rosen and Hanna S. Kassab (eds), Reconceptualising Security in the Americas in the Twenty-First Century (Lexington Books 2015), and Drug War Mexico: Politics, Neoliberalism, and Violence in the New Narco-economy (Zed Books, 2012). Since 2014, he has been a member of the National System of Researchers (SNI Level 1 ) in Mexico. He specialises in the study of neoliberalism, migration, labour unions, and narcotrafficking.

Jonathan D Rosen is a Research Scientist at Florida International University's Jack D Gordon Institute for Public Policy, and a former Research Professor at the Universidad del Mar-Oaxaca, Mexico. He is the author of US-Cuba Relations: Charting a New Path (Lexington Books, 2016), The Losing War: Plan Colombia and Beyond (State University Press of New York, 2015), and Fragile States in the Americas (Lexington Books, 2016). He is co-editor of Drug Trafficking, Organized Crime, and Violence in the Americas Today (University Press of Florida, 2015), and Colombia's Political Economy at the Outset of the Twenty-First Century: From Uribe and Beyond (Lexington Books, 2015), among others.

\title{
Zona de Guerra Acapulco: Tráfico Urbano de Drogas nas Américas
}

\begin{abstract}
Resumo: A hipótese aqui proposta é que Acapulco representa de maneira exemplar a dinâmica de segurança contemporânea nas zonas urbanas das Américas, onde a produção de fronteiras geográficas, políticas e econômicas é agravada pela economia política e geopolítica do narcotráfico, bem como pelas tentativas militarizadas de combatê-lo. O principal argumento desta tese é que a Zona Metropolitana de Acapulco (ZMA) sofreu um processo de alteridade que, geograficamente, politicamente e economicamente, tem resultado em fronteiras visíveis e intangíveis que, à luz do lugar da cidade na economia política e na geopolítica do narcotráfico nas Américas, além de ter levado à militarização das questões relativas ao narcotráfico, levou Acapulco a se classificar entre as 50 cidades mais violentas do mundo. Os resultados e conclusões dessas dinâmicas tornariam as variáveis contidas nesta posição reaplicáveis a outros cenários urbanos do narcotráfico nas Américas.

Palavras-chave: Tráfico de Drogas; Urbanização; Militarização; Acapulco; México; Criminologia; Otherness.
\end{abstract}

Received on 29 April 2017, and approved for publication on 18 June 2017.

\section{(cc) BY-NC} https://creativecommons.org/licenses/by-nc/4.0/ 